Tersedia online di: http://ejournal-balitbang.kkp.go.id/index.php/bawal
e-mail:bawal.puslitbangkan@gmail.com
BAWAL wIDYA RISET PERIKANAN TANGKAP
Volume 10 Nomor 2 Agustus 2018
p-ISSN: 1907-8226
e-ISSN: 2502-6410
BAWAL
Nomor Akreditasi Kementerian RISTEKDIKTI: 21/E/KPT/2018

\title{
BIOLOGI REPRODUKSI IKAN SELAR BENTONG (Selar crumenophthalmus Bloch, 1793) DI PERAIRAN NATUNA, LAUT CINA SELATAN
}

\section{REPRODUCTION BIOLOGY OF BIGEYE SCAD (Selar crumenophthalmus Bloch, 1793) IN THE NATUNA WATERS OF SOUTH CHINA SEA}

\author{
Moh Fauzi *1, Isdradjad Setyobudiandi ${ }^{2}$ dan Ali Suman ${ }^{1}$ \\ ${ }^{1}$ Balai Riset Perikanan Laut, Komplek Raiser Ikan Hias Jalan Raya Bogor KM. 47 Nanggewer Mekar, Cibinong, Bogor Jawa Barat \\ 16912, Indonesia \\ ${ }^{2)}$ Institut Pertanian Bogor, Kampus IPB Dramaga Bogor, Jalan Raya Dramaga, Babakan, Dramaga, Babakan, Dramaga, Bogor, Jawa \\ Barat 16680, Indonesia \\ Teregistrasi I tanggal: 29 Desember 2017; Diterima setelah perbaikan tanggal: 03 Juli 2018; \\ Disetujui terbit tanggal: 23 Agustus 2018
}

\begin{abstract}
ABSTRAK
Ikan selar bentong (Selar crumenophthalmus) merupakan salah satu jenis ikan pelagis kecil yang cukup dominan tertangkap di perairan Natuna, Laut Cina Selatan. Pemanfaatan yang semakin intensif oleh perikanan pukat cincin dikhawatirkan akan mengakibatkan penurunan populasinya. Pengetahuan tentang biologi ikan selar bentong penting sebagai dasar pertimbangan pengelolaannya. Penelitian ini bertujuan menganalisis karakter biologi reproduksi ikan selar bentong di perairan Natuna, meliputi nisbah kelamin, ukuran rata-rata pertama kali matang gonad, ukuran rata-rata tertangkap $\left(\mathrm{L}_{50 \%}\right)$, tingkat kematangan gonad dan dugaaan musim pemijahan. Penelitian dilakukan dengan mengumpulkan ikan contoh hasil tangkapan pukat cincin yang didaratkan di PPN Pemangkat Kalimantan Barat selama 5 tahun (2012-2016). Hasil penelitian menunjukkan nisbah kelamin ikan jantan dan betina adalah 1:1.05. Sebagian besar ikan dalam stadium pematangan (ripening, TKG 3). Ikan bentong mengalami dua musim pemijahan yakni pada awal musim timur (Juni-Juli) dan awal musim barat (Desember-Januari). Ukuran rata-rata tertangkap $\left(\mathrm{L}_{50 \%}\right)$ sebesar $18 \mathrm{~cm}$ FL lebih kecil dari nilai pertama kali matang gonad (Lm) yakni 20,2 cm FL. Nilai Lc yang lebih kecil daripada nilai Lm mengindikasikan terjadinya growth overfishing.
\end{abstract}

Kata Kunci: Biologi reproduksi; ikan selar bentong; Laut Cina Selatan

\section{ABSTRACT}

Bigeye scad (Selar crumenophthalmus) dominantly caught by fishers in the Natuna waters of South China Sea. The intensive exploitation rate of this species by purse seiner led to population decrease. The understanding on biological aspect of bigeye scad is important as a consideration on arranging a proper management. This study aims to analyze biological reproduction of bigeye scad in the Natuna waters, such as sex ratio, length at first maturity, length at first capture, gonad maturity stage and the estimation of spawning season. This research is conducted by sampling the fishes that caught by purse seine fleets which is landed in AFP Pemangkat, West Borneo for 5 years (2012 to 2016). The result showed that sex ratio of males and females were balance by 1:1,05. It dominated by fish that are ripening stage. Spawning season happens twice per year which are in the beginning of east season on June to July and at the beginning of west season on December to January. Length at first capture (L50\%) is $18 \mathrm{cmFL}$ lower than length at first maturity $(\mathrm{Lm}=20,2 \mathrm{cmFL})$ this condition indicated growth overfishing occurred in this fishery.

Keywords: Reproduction biology; bigete scad; South China Sea 


\section{PENDAHULUAN}

Ikan selar bentong/bigeye scad (Selar crumenophthalmus) merupakan salah satu jenis ikan pelagis kecil yang memiliki nilai ekonomis. Ikan ini termasuk famili Carangidae; hidup bergerombol di perairan pantai sampai kedalaman 80 meter; dapat mencapai panjang $30 \mathrm{~cm}$ tetapi pada umumnya ditemukan pada panjang $20 \mathrm{cmTL}$. Makanan utama ikan bentong berupa plankton dan invertebrata benthik (Kimura, 2011). Ikan bentong muda sebagian besar makanannya berupa krustasea (Euphasiids, Decapoda) sedangkan ikan bentong dewasa bersifat predator aktif bagi larva ikan dan awal fase juvenile (Roux \& Conand, 2000). Ikan bentong tersebar di perairan pantai seluruh Indonesia, Teluk Benggala, Teluk Siam, sepanjang pantai Laut Cina Selatan, Philippina, perairan tropis Australia (Genisa, 1999). Di perairan Laut Cina Selatan ikan ini mendominasi hasil tangkapan ikan pelagis kecil bersama dengan ikan layang. Ikan pelagis kecil yang didaratkan di Pelabuhan Perikanan Nusantara (PPN) Pemangkat Kalimantan Barat umumnya berasal dari hasil tangkapan pukat cincin dan mendominasi $77 \%$ dari total produksi ikan yang didaratkan (Budiarti, 2015).

Sejak tahun 1985 armada pukat cincin berasal dari Pulau Jawa telah memperluas daerah penangkapan ikan hingga ke perairan Laut Cina Selatan. Selain perluasan daerah penangkapan, peningkatan jumlah armada pukat cincin juga dapat mengakibatkan semakin menurunnya nilai laju tangkap (Hariati et al., 2009). Statistik perikanan tangkap menunjukkan terjadi penurunan laju tangkap di seluruh Laut Cina Selatan. Sejak tahun 2003 hingga tahun 2014 penurunan laju tangkap berbanding terbalik dengan semakin meningkatnya upaya penangkapan (Anonim, 2014). Rata-rata CPUE alat tangkap pukat cincin cenderung menurun, rata-rata tertinggi terjadi pada tahun $2009(21,4$ ton/trip) dan tahun 2010 (19,8 ton/trip), kemudian terjadi penurunan drastis pada tahun 2011 (10,2 ton/trip). Hal ini terjadi karena jumlah upaya penangkapan (trip) pada tahun 2011 meningkat hampir dua kali lipat dibandingkan tahun 2009 dan 2010, tetapi tidak diikuti oleh peningkatan produksi. Penurunan nilai CPUE juga terjadi pada ikan selar bentong $S$. crumenophthalmus. Produksi ikan selar bentong tidak terpengaruh pada musim penangkapan, namun pada tahun 2009 hingga 2013, produksi dan laju tangkapnya semakin menurun (Budiarti, 2015).

Pemanfaatan sumberdaya perikanan yang tidak terkendali dapat menyebabkan penurunan populasinya di suatu perairan. Pentingnya mengetahui status perikanan selar bentong akibat tekanan penangkapan di Laut Cina Selatan merupakan hal penting sebagai dasar pengelolaannya. Informasi tentang biologi perikanan yang mencakup dinamika populasi, parameter reproduksi, pertumbuhan dan kematian diperlukan untuk merumuskan program pengelolaan yang berhasil (Widodo \& Suadi, 2006). Penelitian ini bertujuan untuk menganalisis biologi reproduksi ikan selar bentong (S. crumenophthalmus), meliputi : nisbah kelamin, rata-rata ukuran pertama kali matang gonad, tingkat kematangan gonad dan dugaaan musim pemijahan.

\section{BAHANDANMETODE Waktu dan Lokasi Penelitian}

Penelitian berlangsung selama 5 tahun yakni dari tahun 2012 hingga tahun 2016, yang merupakan bagian dari kegiatan penelitian BRPL (Balai Riset Perikanan Laut) di Wilayah Pengelolaan Perikanan (WPP) 711 Laut Cina Selatan dan Selat Karimata. Lokasi pengambilan sampel dilakukan di PPN Pemangkat, Kabupaten Sambas Kalimantan Barat, yang merupakan pusat pendaratan armada pukat cincin terbesar di WPP 711. Sampel ikan selar bentong berasal dari hasil tangkapan armada pukat cincin yang beroperasi di perairan Natuna dan sekitarnya (Gambar 1).

\section{Pengumpulan Data}

Pengumpulan data dilakukan pada waktu survei lapangan dibantu tenaga enumerator untuk mendapatkan contoh ikan yang mewakili. Pengambilan contoh (sample) ikan dilakukan secara acak pada hasil tangkapan pukat cincin 2 sampai 4 kali per bulan dengan jumlah ikan contoh proporsional menurut kelas panjang, sehingga total ikan contoh yang diukur rata-rata 250 ekor per bulan. Pengukuran dilakukan terhadap ikan contoh berukuran panjang cagak (fork length) $15 \mathrm{~cm}$ atau lebih (individu ikan dewasa/adult fish). Pra pengambilan contoh juga dilakukan untuk menentukan ukuran minimum pengukuran biologi saat gonad jantan dan betina dapat dibedakan. Ikan contoh merupakan bagian dari 1 keranjang $( \pm 50 \mathrm{~kg})$ contoh hasil tangkapan (sub sample, terdiri atas beberapa spesies ikan) yang diambil secara acak dari palkah suatu kapal contoh yang sedang bongkar (Suwarso et al., 2008).

Karakter individu yang diukur meliputi ukuran panjang (panjang total dan panjang cagak, dalam $\mathrm{cm}$ ), bobot tubuh dalam keadaan segar (dalam gram), sex (jenis kelamin), tingkat kematangan gonad, dan bobot gonad segar (dalam gram). Tingkat kematangan gonad ditentukan secara visual mengikuti skala kematangan gonad standard (five point maturity scale for partial spawners) yang mengacu pada Holden \& Raitt (1974) (Tabel 1). 


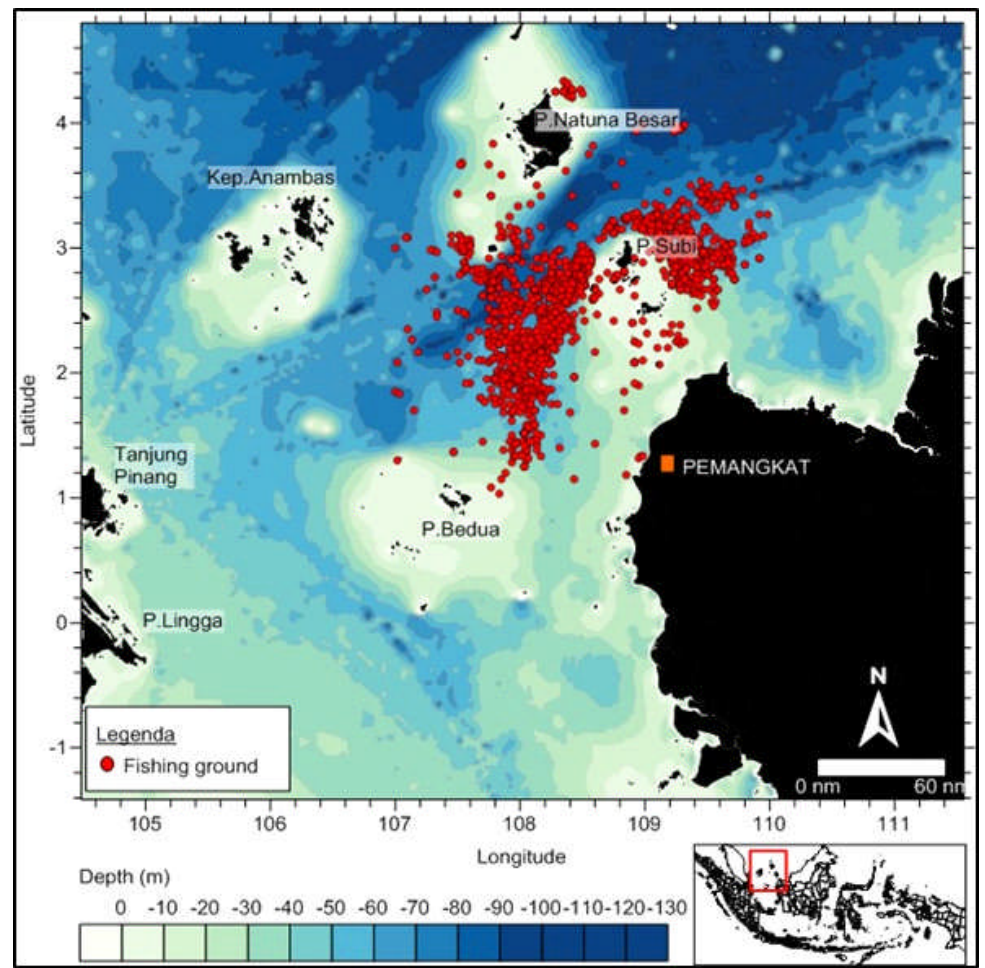

Gambar 1. Daerah penangkapan pukat cincin dan lokasi pendaratan ikan di Pemangkat Kalimantan Barat. Sumber data: Logbook Penangkapan Ikan oleh PSDKP Pemangkat Kalimantan Barat.

Figure 1. Fishing ground of purse seine and landing site in Pemangkat, West Kalimantan. Source: Fishing Logbook by PSDKP Pemangkat, Sambas, West Kalimantan.

Tabel 1. Kriteria Tingkat Kematangan Gonad umum yang diterapkan pada ikan bentong (S. crumenophthalmus). Table 1. Common gonad maturity stage criteria applied for bigeye scad ( $\underline{\text { S. crumenophthalmus }}$ )

\begin{tabular}{|c|c|c|}
\hline TKG & Tingkat/Stage & Deskripsi/Description \\
\hline $\mathrm{I}$ & Dara & $\begin{array}{l}\text { Ovari dan testis kecil dan menempati 1/3 dari panjang rongga badan. Ovari jernih } \\
\text { berwarna kemerahan;testis keputih-putihan. Butiran telur tidak nampak. }\end{array}$ \\
\hline II & $\begin{array}{l}\text { Dara } \\
\text { berkembang }\end{array}$ & $\begin{array}{l}\text { Ovari dan testis sekitar } 1 / 2 \text { dari panjang rongga badan. Ovari berwarna merah- } \\
\text { jingga, testis berwarna putih. Butiran telur tidak nampak dengan mata telanjang }\end{array}$ \\
\hline III & Mulai matang & $\begin{array}{l}\text { Ovari dan testis menempati sekitar } 2 / 3 \text { dari panjang rongga badan. Ovari berwarna } \\
\text { kuning-oranye, butiran telur nampak. Testis berwarna putih krem Ovari dengan } \\
\text { pembuluh darah di permukaannya. Telur masih opaque (gelap) dan belum ada } \\
\text { telur yang transparan. }\end{array}$ \\
\hline IV & Matang & $\begin{array}{l}\text { Ovari dan testis kira-kira sampai memenuhi rongga badan. Ovari berwarna jingga- } \\
\text { merah muda dengan pembuluh-pembuluh darah, telur besar-besar transparan dan } \\
\text { matang. Testis putih-krem dan lunak. }\end{array}$ \\
\hline V & Mijah & $\begin{array}{l}\text { Ovari dan testis menyusut hingga } 1 / 2 \text { dari rongga badan, dinding tebal. Di dalam } \\
\text { ovari mungkin masih tersisa telur-telur opaque dan ripe yang mengalami } \\
\text { desintegrasi akibat penyerapan, gelap atau translucent. Testis lembek }\end{array}$ \\
\hline
\end{tabular}

Ukuran rata-rata panjang ikan tertangkap $\left(\mathrm{L}_{50 \%}\right)$ diperoleh dari ukuran panjang cagak ikan sampel yang diukur secara serial/ bulanan. Pengukuran panjang cagak (FL) dalam satuan millimeter menggunakan kertas ukur (measuring paper). Data yang diperoleh kemudian dikelompokkan serial bulanan menurut selang kelas panjang $5 \mathrm{mmFL}$.

\section{Analisis Data}

Karakter biologi reproduktif dan dugaan ukuran pertama kali matang gonad (size at first maturity) didasarkan pada data kematangan gonad (TKG) dari kelompok ikan dewasa (adult). Pada Gambar 2 diberikan scatter diagram dari gonado somatic index (GSI) menurut ukuran, yang menunjukkan bagaimana memisahkan individu ikan dewasa (adults, GSI>4) dan belum dewasa (GSI<4). 


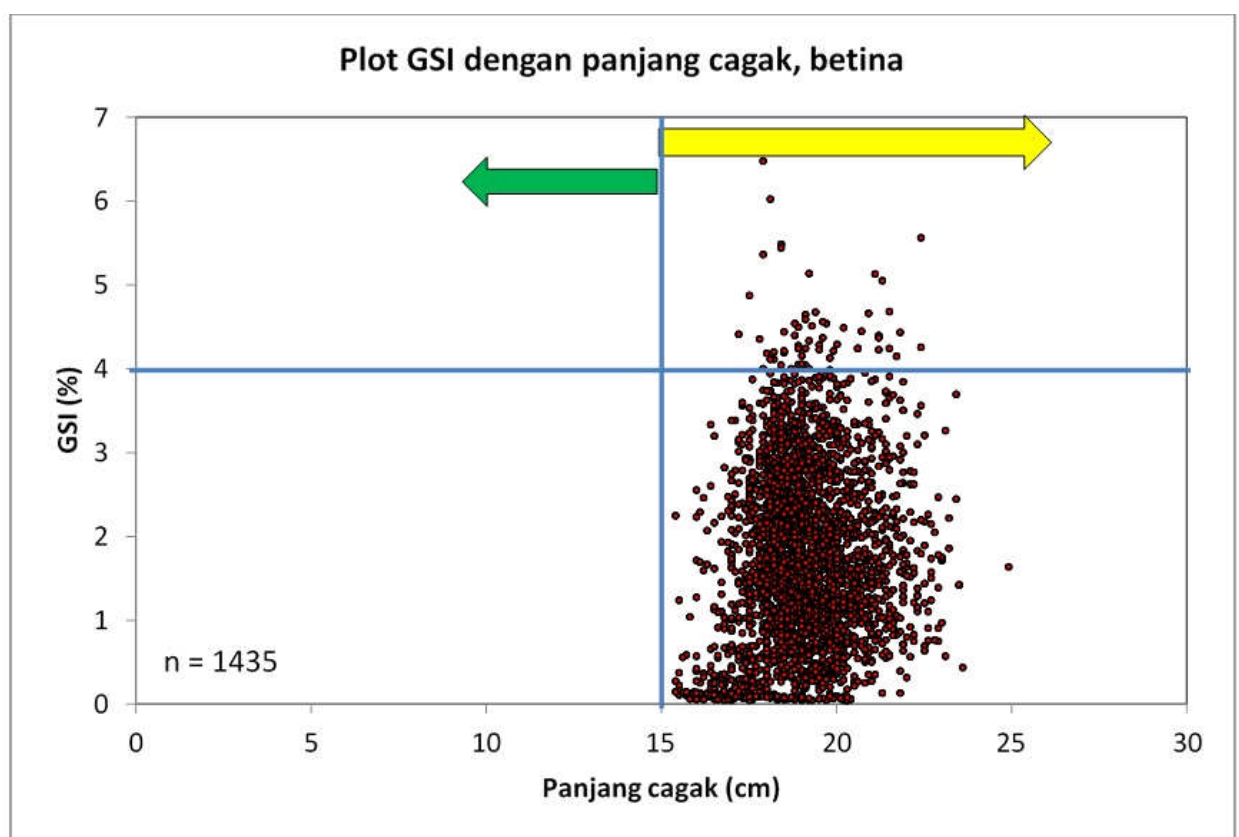

Gambar 2. Scatter diagram gonado somatic index (GSI) menurut ukuran panjang dan contoh pemisahan ikan dewasa (adults, GSI $>4$ ) dan belum dewasa (subadults, GSI $<4$ ).

Figure 2. Scatter diagram of the fish size at gonado somatic index (GSI) values shows how to separate the adults and sub adults fishes according to the size and gonado somatic index value.

Nisbah kelamin dihitung berdasarkan rumus Effendie (2002), yaitu

$\mathrm{X}=\mathrm{J} / \mathrm{B}$

Dimana $\mathrm{X}=$ nisbah kelamin; $\mathrm{B}=$ jumlah ikan betina; $\mathrm{J}=$ jumlah ikan jantan.

Selanjutnya untuk melihat apakah jumlah ikan jantan dan betina seimbang dilakukan pengujian menggunakan uji chi-square $\left(\mathrm{X}^{2}\right)$ (Steel \& Torrie 1993).

\section{Ukuran Pertama Kali Matang Gonad (length at first maturity, Lm)}

Ukuran pertama kali matang gonad (Lm) diduga dengan cara Spearman-Karber seperti yang diusulkan oleh Udupa (1986) sebagai berikut:

$\mathrm{m}=\mathrm{Xk}+(\mathrm{X} / 2)-(\mathrm{XÓ}$ pi $)$

Dimana: $\mathrm{m}=\log$ panjang ikan pada kematangan gonad pertama; $\mathrm{Xk}=\log$ nilai tengah kelas panjang dimana semua ikan (100\%) sudah matang gonad; $\mathrm{Pi}=$ proporsi ikan matang pada kelas I dimana pi $=$ ri/ni apabila $n i=n i+1 ; \mathrm{Ri}=$ jumlah ikan matang pada kelas panjang ke i maka panjang ikan pada waktu mencapai kematangan gonad pertama (M) adalah $\mathrm{M}=\operatorname{antilog}(\mathrm{m})$. Jika á = 0,05 maka batas-batas kepercayaan 95\% dari (m) adalah : Antilog[m $\pm 1.961(\mathrm{X} 2$ $\mathrm{S}(\mathrm{pi}$ *qi)/(ni-1))].

\section{Ukuran Rata-rata Tertangkap $\left(\mathbf{L}_{50 \%}\right)$}

Pendugaan rata-rata ukuran pertama kali tertangkap dilakukan dengan membuat grafik hubungan antara panjang ikan (sumbu X) dengan jumlah ikan (sumbu Y) sehingga diperoleh kurva berbentuk S. Nilai yaitu panjang pada $50 \%$ kali tertangkap dihitung dengan persamaan sebagai berikut (Jones 1976 dalam Sparre dan Venema 1999):

$$
S_{L} \text { est }=\frac{1}{1+\exp \left(S_{1}-S_{2} * L\right)}
$$

$\operatorname{Ln}\left[\frac{1}{S L}-1\right]=S_{1}-S_{2} * L$

$L_{50 \%}=\frac{S_{1}}{S_{2}}$

dimana;

SL $\quad=$ kurva logistik; $\mathrm{S}_{1}=\mathrm{a} ; \mathrm{S}_{2}=\mathrm{b}$

$S_{1}$ dan $S_{2}=$ konstanta pada rumus kurva logistik

\section{Indek Kematangan Gonad dan Dugaan Musim Pemijahan}

Indek kematangan gonad (IKG) dirumuskan (Effendie, 1979) sebagai berikut : 
$I K G=\frac{B g}{B t} \times 100 \%$

Dimana, $\mathrm{IKG}=$ indek kematangan gonad $(\%) ; \mathrm{Bg}=$ berat gonad $(\mathrm{gram}) ; \mathrm{Bt}$ (berat somatik)= berat tubuh total - berat gonad segar (gram).

Musim pemijahan diduga berdasarkan pada pola fluktuasi bulanan dari nilai Gonadosomatic index (GSI) yang ditegaskan oleh data perkembangan tingkat kematangan (TKG).

\section{HASIL DAN BAHASAN \\ Hasil}

\section{Sebaran Ukuran Sampel}

Selama periode penelitian telah diukur sampel ikan selar bentong sebanyak 2864 ekor yang terdiri dari ikan jantan sebanyak 1.466 ekor dan betina sebanyak 1.398 ekor. Kisaran panjang ikan jantan 13,7-24,9 cm FL (panjang rata-rata 19,2 cmFL; modus pada kelas panjang 19-19,5 cmFL). Kisaran panjang ikan betina 14,9-23,4 cmFL (panjang rata-rata $19 \mathrm{cmFL}$, modus pada kelas panjang 18,5-19 cmFL (Gambar 3).

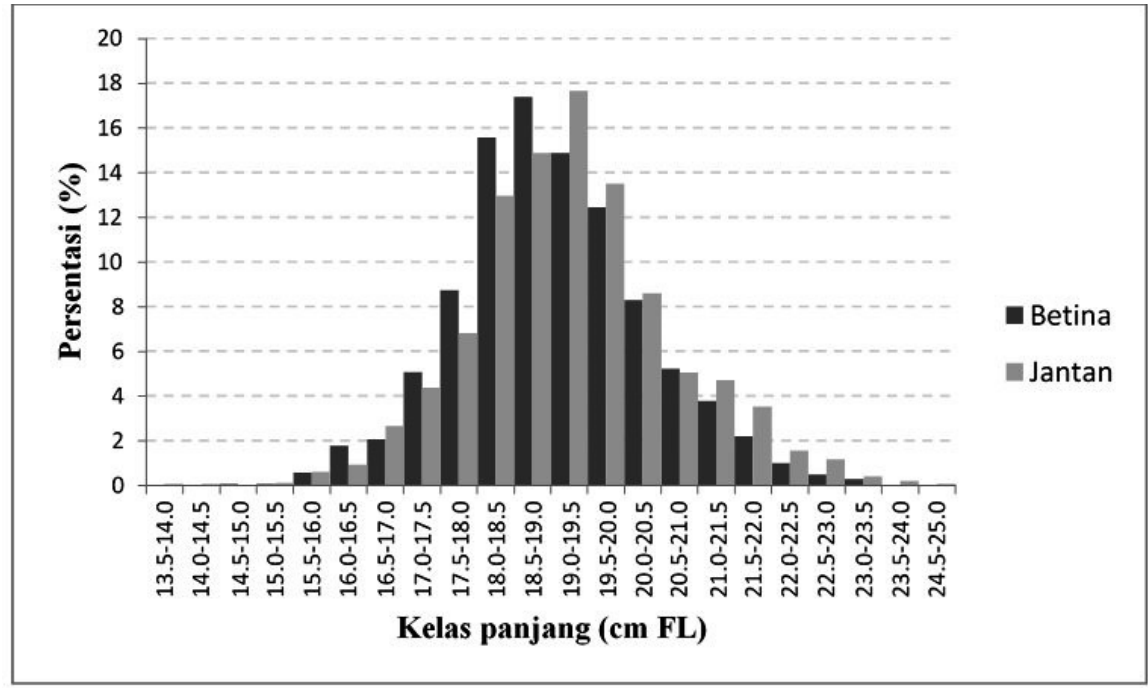

Gambar 3. Sebaran ukuran ikan contoh selar bentong (S. crumeophthalmus) tertangkap di Laut Cina Selatan, 20122016.

Figure 3. Length requency of bigeye scad (S. crumenophthalmus) sample caught in South China Sea, 2012-2016.

\section{Ukuran Rata-rata Tertangkap $\left(L_{50 \%}\right)$}

Ukuran rata-rata tertangkap $\left(\mathrm{L}_{50 \%}\right)$ ikan selar bentong di Laut Cina Selatan tahun 2012-2016 berfluktuasi dengan rata-rata kumulatif pada panjang cagak $18 \mathrm{cmFL}$. $\mathrm{LC}_{50 \%}$ terpendek pada tahun 2012 sebesar $16,2 \mathrm{cmFL}$ dan terpanjang pada tahun 2016 sebesar $18,8 \mathrm{cmFL}$ (Lampiran 1). Disajikan pula nilai ukuran rata-rata tertangkap pada peluang lolosnya ikan sebesar $25 \%$ dan $75 \%$ (Tabel 2).

Tabel 2. Ukuran rata-rata tertangkap ikan selar bentong (S. crumenophthalmus) tertangkap di Laut Cina Selatan tahun 2012-2016

Table 2. $\quad$ Length at first capture of bigeye scad (S. crumenophthalmus) caught in South China Sea 2012-2016

\begin{tabular}{crrrrr}
\hline & \multicolumn{5}{c}{ Tahun/Year } \\
Lc & $\mathbf{2 0 1 2}$ & $\mathbf{2 0 1 3}$ & $\mathbf{2 0 1 4}$ & $\mathbf{2 0 1 5}$ & $\mathbf{2 0 1 6}$ \\
\hline $\mathrm{L}_{50 \%}$ & 16,2 & 17,6 & 17,9 & 17,6 & 18,8 \\
$\mathrm{~L}_{25 \%}$ & 14,8 & 16,6 & 16,8 & 16,6 & 18,1 \\
$\mathrm{~L}_{75 \%}$ & 17,6 & 18,7 & 18,9 & 18,6 & 19,6 \\
\hline
\end{tabular}

\section{Nisbah Kelamin}

Nisbah kelamin antara ikan selar bentong jantan dan betina adalah 1:1,05 $(\mathrm{n}=2845)$. Berdasarkan hasil uji terhadap 39 bulan pengamatan diperoleh nilai $\mathrm{X}^{2}$ hitung sebesar 46,3646 lebih kecil dari $X^{2}$ tabel sebesar 53,3835. Nilai $X^{2}$ hitung lebih kecil dari nilai $X^{2}$ tabel tolak $\mathrm{H}$ nol: artinya nisbah kelamin antara ikan jantan dan betina dalam kondisi seimbang mengikuti pola $1: 1$ (Chi square, $\mathrm{p}=0.05)$. Gambar 4 menunjukkan nisbah kelamin ikan selar bentong menurut waktu pengamatan dan kelas panjang cagak. Pada gambar 4 a terlihat bahwa nisbah kelamin berfluktuasi menurut musim. Ikan betina mendominasi pada awal musim barat dan pada saat musim timur sedangkan ikan jantan mendominasi pada kedua musim peralihan. Hal ini diperkirakan berkaitan dengan aktivitas reproduksinya. 
Pada gambar 4b nampak bahwa ikan jantan mendominasi pada saat awal dewasa (ukuran15-16 cmFL) dan saat ikan telah matang gonad dan semakin mendominasi hingga mencapai ukuran maksimalnya (19-25 cmFL). Dominasi ikan betina terjadi saat ikan mencapai ukuran reproduktif $(16-19 \mathrm{cmFL})$. Hal ini diperkirakan terkait dengan ukuran reproduksinya.

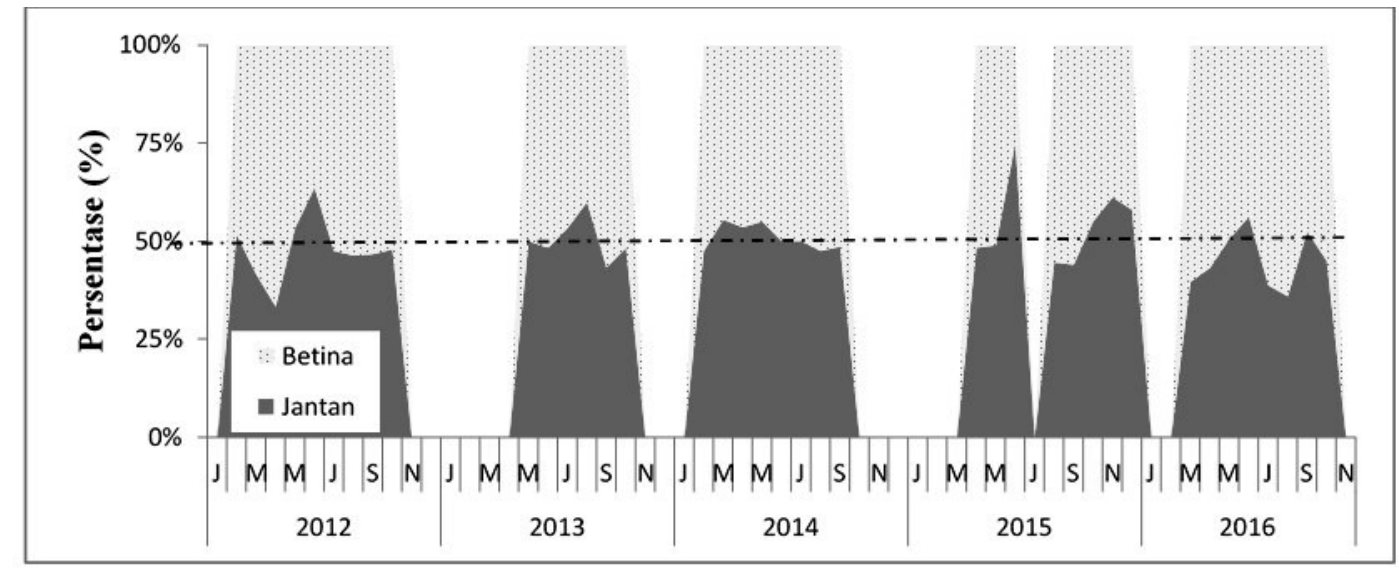

(a)

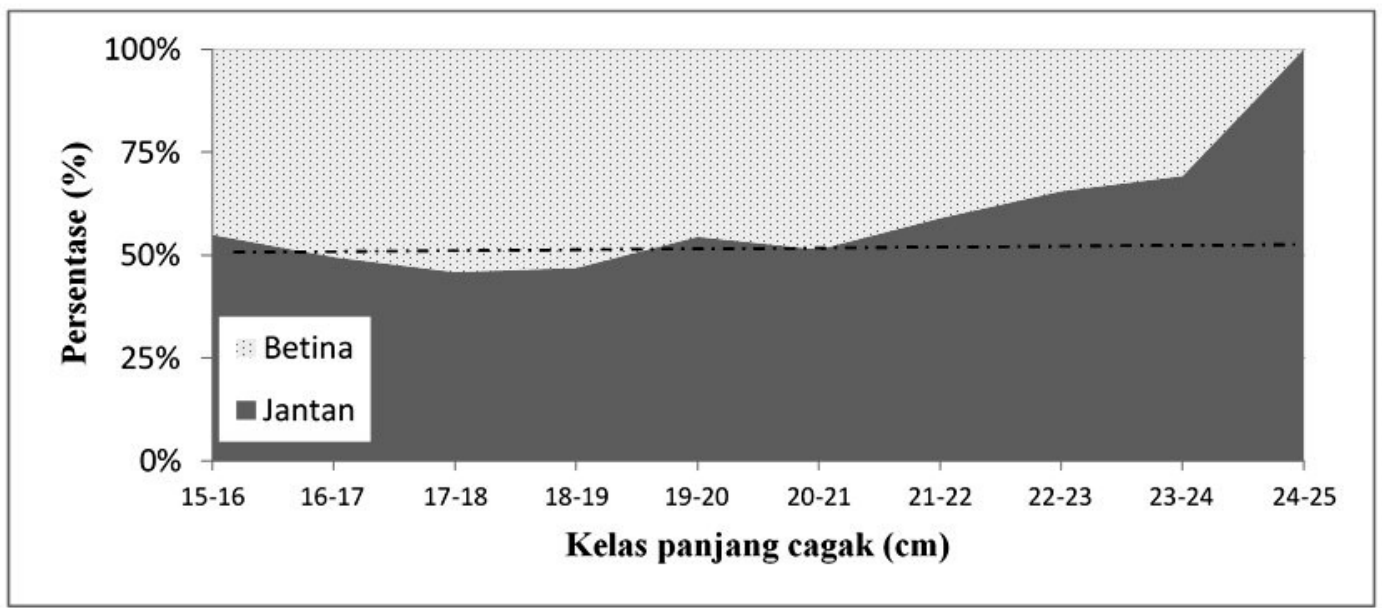

(b)

Gambar4. Nisbah kelamin ikan selar bentong di perairan Natuna menurut waktu (a) dan kelas panjang cagak (b) selama tahun 2012-2016.

Figure 4. Sex ratio of bigeye scad according to time (a) and forklength groups (b) in Natuna Waters on 20122016.

\section{Perkembangan Kematangan Gonad}

Perkembangan reproduksi ikan berjalan seiring dengan bertambahnya ukuran atau umur yang diketahui melalui ukuran dan bentuk gonadnya (ovarium). Semakin besar ukuran ikan maka semakin matang seksualitasnya dan semakin besar gonadnya sebagai akibat bertambahnya ukuran telur (ova). Pada saat TKG 1 (immature) dimana proporsi ovarium (gonad betina) hanya 1/3 dari rongga badan, rata-rata nilai GSI adalah terendah ( GSI ratarata0,46\%); Ovarium pada TKG 2 berkembang (maturing) menjadi $1 / 2$ dari panjang rongga badannya sehingga meningkatkan proporsinya(1,19\%). Pada TKG 3 dimana gonad dalam proses pematangan (ripening), proporsinya meningkat menjadi 2/3 dari panjang rongga badannya (GSI rata-rata $2,38 \%$ ). Diduga proses pematangan merupakan proses terlama karena sebaran nilai GSInya umumnya lebih panjang. TKG 4 merupakan kondisi dimana ovarium telah matang (mature atau ripe), GSI berada pada nilai maksimalnya (4,25\%). Pada saat pemijahan (TKG 5 / spent), ovarium dilepaskan dari gonad. Kondisi ini menyebabkan penyusutan ovarium hingga $1 / 2$ dari panjang rongga badan $(1,35 \%)$. Sebaran indek kematangan gonad (IKG) berdasarkan tingkat kematangan gonad (TKG) diperlihatkan pada Tabel 3. 
Tabel 3. Sebaran GSI menurut tingkat kematangan gonad (TKG) ikan selar bentong (S. crumenophthalmus) di Laut Cina Selatan, 2012-2016

Table 3. The statistic values of gonado somatic index of bigeye scad according to the maturity stage in South China Sea, 2012-2016

\begin{tabular}{cccc}
\hline TKG/Maturing Stage & $\begin{array}{c}\text { Kisaran IKG/ } \\
\text { Range of GSI }\end{array}$ & $\begin{array}{c}\text { Rata-rata IKG/ } \\
\text { Mean of GSI }\end{array}$ & $\begin{array}{c}\text { Jumlah sampel/No. of } \\
\text { Sample }\end{array}$ \\
\hline TKG 1 & $0,044-0,999$ & 0,46 & 599 \\
TKG 2 & $0,806-1,534$ & 1,19 & 634 \\
TKG 3 & $1,478-3,858$ & 2,38 & 1461 \\
TKG 4 & $3,692-6,477$ & 4,25 & 103 \\
TKG 5 & $0,437-1,863$ & 1,35 & 10
\end{tabular}

Total : 2892

Komposisi tingkat kematangan gonad ikan selar bentong menunjukkan bahwa sebagian besar ikan masih dalam tahap awal kematangan (maturing, TKG 3) $51 \%$ dan ikan-ikan muda (immature, TKG 1 dan 2) 43\%. Ikan dengan kondisi matang seksual (mature, TKG 4) sebesar $4 \%$ sedangkan pasca memijah/spent kurang dari $1 \%$. Komposisi TKG bulanan ikan selar bentong mengalami perubahan setiap periode yang berkaitan dengan musim pemijahan. Pada Gambar 5 terlihat bahwa pada ikan TKG 4 (mature) muncul dengan proporsi terbesar pada dua periode yakni awal musim barat (8\%) dan awal musim timur (6\%). Ikan dengan kondisi pasca memijah (spent, TKG 5) juga terdapat pada awal musim barat $(2 \%)$ dan awal musim timur $(1,2 \%)$. Ikan dengan kondisi belum matang (immature, TKG 1) mulai muncul pada akhir musim peralihan $2(46 \%)$ dan akhir musim barat (92\%). Perubahan komposisi tingkat kematangan sexual menurut waktu penelitian ditunjukkan pada Gambar 5.

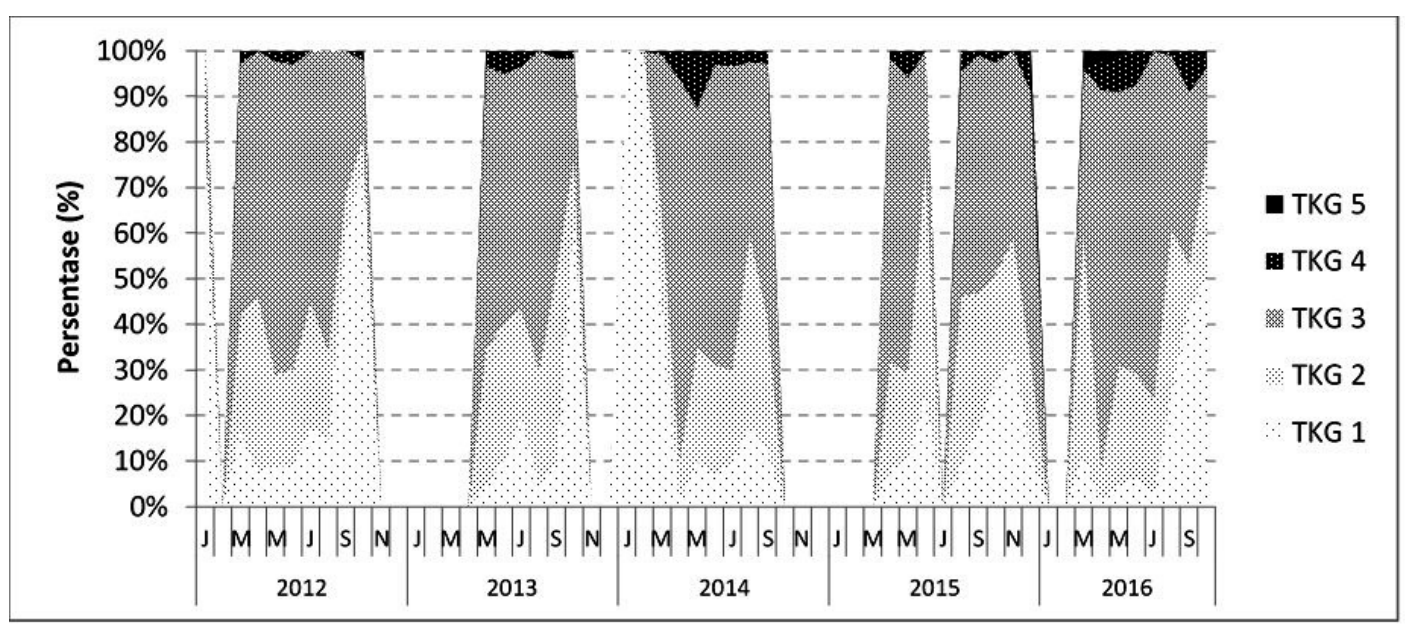

Gambar 5. Perubahan kematangan gonad (\%) ikan selar bentong (S. crumenophthalmus) tertangkap di Laut Cina Selatan.

Figure 5. Changes of \% maturity of bigeye scad (S. crumenophthalmus) caught in South China Sea.

\section{Ukuran Pertama Kali Matang Gonad (Lm)}

Hasil analisis pada taraf kepercayaan $95 \%$ menunjukkan ikan selar bentong betina memiliki ukuran pertama kali matang gonad pada panjang cagak 20,2 cmFL namun jika dirinci per tahun memperlihatkan nilai yang bervariasi. Nilai Lm pada tahun 2012 sebesar 19,3 cmFL kemudian $20,8 \mathrm{cmFL}$ pada tahun 2013. Nilai Lm yang sama pada tahun 2014-2016 yakni pada ukuran 20,2 cmFL. Pada Tabel 4 disajikan variasi perubahan nilai Lm ikan selar bentong jantan dan betina per tahun selama 2012-2016.

\section{Fluktuasi Nilai GSI dan Dugaan Musim Pemijahan}

Nilai GSI berfluktuasi setiap bulannya dan mengalami peningkatan maksimum ketika ikan akan memijah. Terjadi dua kali periode puncak GSI. Nilai GSI rata-rata terendah (lembah pertama) terjadi pada akhir musim barat $(0,26 \%)$ kemudian semakin meningkat yang menunjukkan terjadinya proses pematangan gonad dan mencapai puncaknya pada puncak musim timur $(2,01 \%)$. Pada musim peralihan 2 GSI menurun secara signifikan mencapai nilai minimum (lembah kedua) dan meningkat kembali sampai puncaknya pada awal musim barat. Fluktuasi nilai GSI ikan selar bentong betina secara bulanan selama (2012-2016) dapat dilihat pada Gambar 6. 
Tabel 4. Ukuran panjang saat pertama kali matang gonad ikan bentong (S. crumenophthalmus) betina di Laut China Selatan

Table 4. Length at first maturity of the bigeye scad (S. crumenophthalmus) female in South China Sea

\begin{tabular}{cccc}
\hline \multirow{2}{*}{ Tahun/Year } & Nilai Lm $(\mathbf{c m F L})$ & \multicolumn{2}{c}{ 95\% CL } \\
\cline { 3 - 4 } & & MU & ML \\
2012 & 19,3 & 19,7 & 18,9 \\
2013 & 20,8 & 21,1 & 20,5 \\
2014 & 20,2 & 20,4 & 20 \\
2016 & 20,2 & 20,5 & 20 \\
\hline
\end{tabular}

Keterangan/Remark: MU: batas atas ML: batas bawah log terakhir ukuran ikan saat pertama matang gonad.

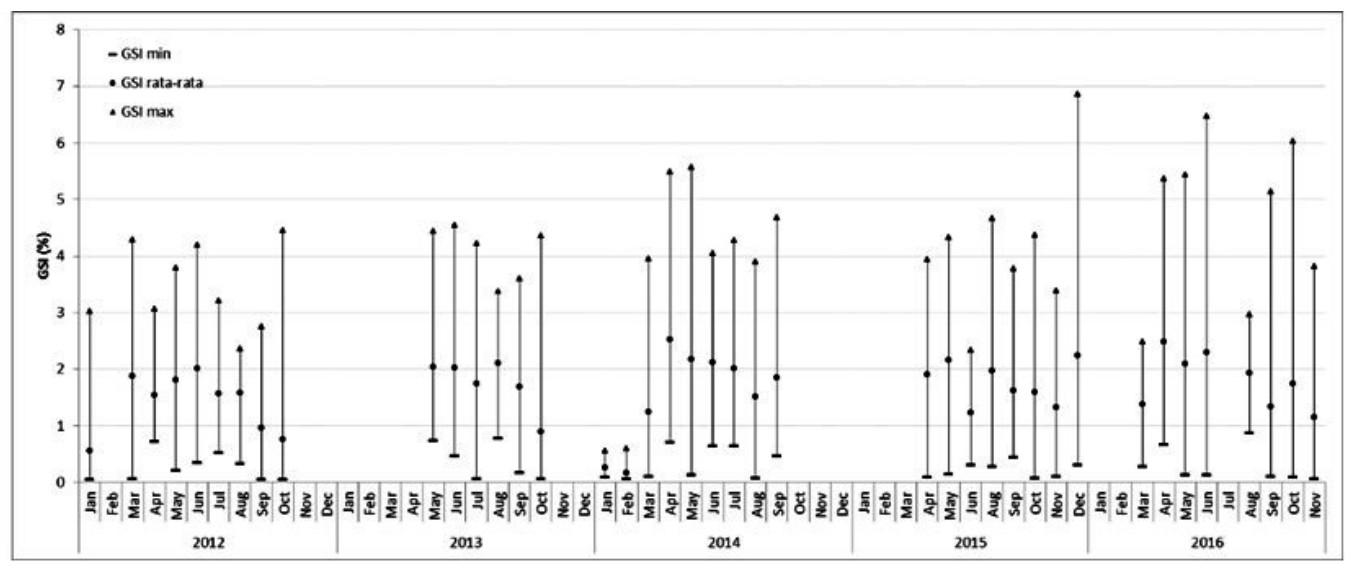

Gambar 6. Fluktuasi rata-rata gonado somatic index (GSI) ikan selar bentong (S. crumenophthalmus) betina tertangkap di Laut Cina Selatan, 2012-2016.

Figure 6. Monthly fluctuation of gonado somatic index (GSI) value (average $\pm S D$ ) of bigeye scad (S. crumenophthalmus) female caught in South China Sea.

Fluktuasi kumulatif GSI memperlihatkan dua kali dua kali musim pemijahan yakni pada awal musim barat periode puncak GSI (Gambar 7). Kedua periode ini menunjukkan bahwa ikan selar bentong diduga mengalami dan awal musim timur.

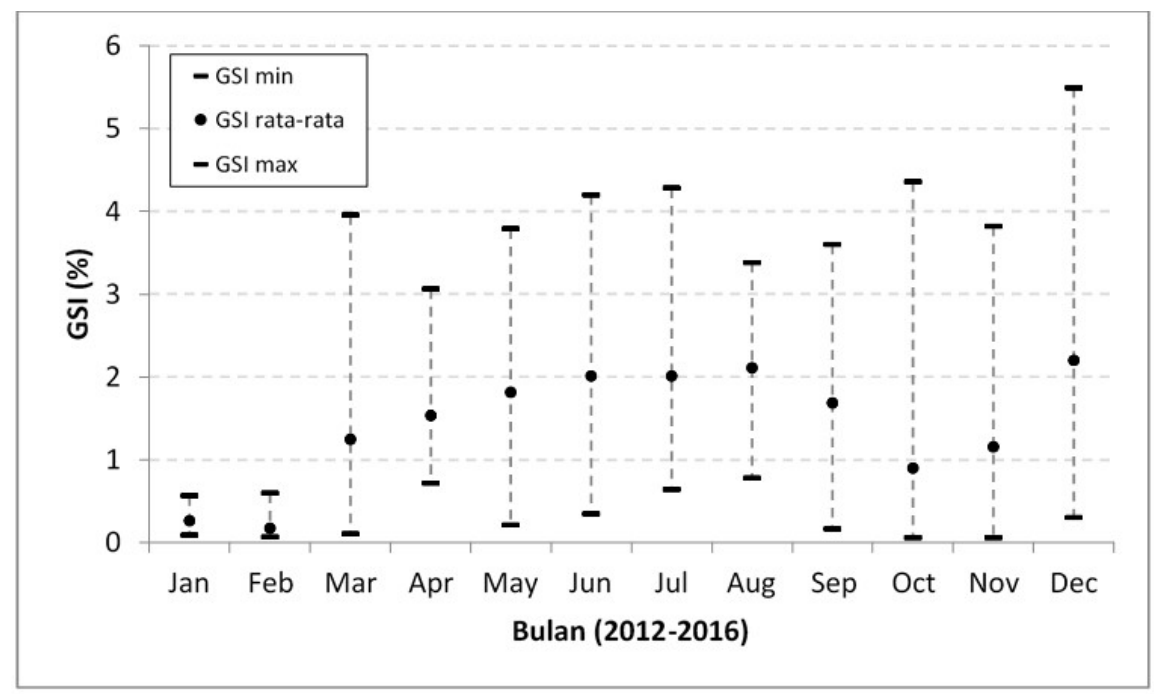

Gambar 6. Fluktuasi kumulatif gonado somatic index (GSI) menurut bulan ikan selar bentong (S. crumenophthalmus) betina tertangkap di Laut Cina Selatan, 2012-2016.

Figure 6. Monthly cummulative fluctuation of gonado somatic index (GSI) value (average \pm SD) of bigeye scad (S. crumenophthalmus) female caught in South China Sea (2012-2016). 


\section{Bahasan \\ Sebaran Ukuran Ikan}

Ukuran ikan jantan berkisar antara 13,7-24,9 cm FL, dengan rata-rata 19,2 cm FL; ikan betina berkisar antara 14,9-23,4 cm FL, dengan rata-rata $19 \mathrm{~cm}$ FL. Ikan jantan memiliki ukuran yang lebih panjang dibandingkan ikan betina. Secara keseluruhan sebaran ukuran panjang ikan selar bentong di perairan Natuna tersebar normal dengan satu modus. Sebagian besar ikan yang tertangkap merupakan ikan-ikan dalam kondisi menjelang matang seksual (ripening, TKG 3) yang jumlahnya 51\%. Faizah et al. (2017) menemukan ikan bentong di perairan utara Kwandang memiliki kisaran panjang cagak 13,5-21 cmFL (Faizah et al., 2017); di perairan Maluku Tengah dan Utara 17-26 cm FL (Syam et al., 2003). Nikolsky (1963) menyatakan bahwa perbedaan ukuran ikan juga dipengaruhi oleh kondisi lingkungan, kelimpahan dan ketersediaan makanan, suhu dan cahaya pada tiap perairan yang berbeda.

\section{Nisbah Kelamin}

Pengamatan terhadap nibah kelamin ikan dilakukan untuk mengetahui keseimbangan populasi ikan jantan dan betina. Perbandingan jenis kelamin juga dapat digunakan untuk menduga keberhasilan pemijahan, yaitu dengan melihat imbangan jumlah ikan jantan dan ikan betina di suatu perairan, juga berpengaruh terhadap produksi, rekruitmen, dan konservasi sumberdaya ikan tersebut (Effendie, 2002). Nisbah kelamin ikan selar bentong jantan dan betina di perairan Natuna diduga 1:1.05. Dari uji chi square menunjukkan kondisi seimbang secara statistic yakni 1:1. Hasil penelitian ini sama dengan penelitian yang dilakukan Faizah et al., (2014) di perairan Kwandang (Gorontallo Utara) yakni 1:1.05, (Syam et al., 2003) di perairan Maluku Tengah dan Maluku Utara, Iwai (1996) di perairan Hawaii. Penelitian oleh Zamroni \& Suwarso (2011) menunjukkan perbandingan yang tidak seimbang antara betina dan jantan yakni yakni 1:1.4 di Laut Banda.

Berdasakan struktur ukuran ikan terlihat perbedaan yang signifikan pada nisbah kelamin ikan selar bentong (jantan dan betina) dimana pada ikan-ikan besar (kelas panjang >19 cmFL populasi didominasi ikan berjenis kelamin jantan bahkan pada kelas yang lebih besar diatas $24 \mathrm{cmFL}$ hanya terdiri dari ikan jantan.

Nisbah kelamin 1 : 1 merupakan kondisi yang ideal (Ball \& Rao 1984). Tetapi di alam sering terjadi penyimpangan dari kondisi yang ideal, hal ini disebabkan oleh adanya pola tingkah laku bergerombol antara ikan jantan dan ikan betina, perbedaan laju mortalitas dan pertumbuhan. Apabila dilihat dari segi laju pemijahan, bahwa perbandingan kelamin dapat berubah menjelang dan selama proses pemijahan (Nikolsky 1963). Dalam ruaya ikan untuk memijah terjadi perubahan nisbah kelamin secara teratur. Pada awalnya ikan jantan dominan daripada ikan betina, kemudian nisbah kelamin berubah menjadi 1:1 diikuti dengan dominansi ikan betina. Pada penelitian ini ikan betina mendominasi pada saat musim pemijahan (awal musim barat dan saat musim timur) sedangkan ikan jantan mendominasi pada kedua musim peralihan.

\section{Perkembangan Kematangan Gonad}

Perkembangan kematangan seksual seiring dengan perkembangan ukuran tubuh sebagai fungsi dari umur. Tingkat kematangan gonad (TKG) semakin meningkat sejalan dengan pertumbuhan ikan. Perkembangan gonad ikan dapat dilihat dari nilai indeks kematangan gonad (GSI). Nilai GSI mencapai maksimum ketika gonad mencapai akhir dari proses reproduksinya yaitu pada saat akan memijah. Kondisi ini terjadi ketika ikan berada pada tingkat kematangan gonad 4 (TKG IV, mature) (Tabel 2). Nilai GSI puncak umumnya berada pada TKG 4 dimana volume gonad mencapai $2 / 3$ memenuhi rongga tubuh ikan tersebut. Nilai GSI kemudian akan menurun drastis setelah ikan memijah (TKG 5). Jumlah ikan dengan kondisi "spent" (TKG 5) sangat sedikit didapatkan (kurang dari 1\%). Hal ini diduga karena singkatnya periode waktu dari memijah menuju pembentukan kembali sel-sel telur. Sebagian besar ikan selar bentong ditemukan dalam masa awal kematangan seksual (TKG 3) sekitar 51\%, ikan-ikan muda/immature (TKG 1 dan 2) sekitar 43\%, ikan matang gonad (TKG 4) ditemukan sekitar 4\%) sedang ikan yang dalam kondisi memijah (spent, TKG 5) hanya (1\%). Suwarso \& Sadhotomo (1995) menyebutkan bahwa ikan selar bentong di laut Jawa dalam kondisi belum matang ('immature': TKG 1, 2 dan 3) merupakan specimen yang dominan dalam populasi (98\%), sedangkan individu yang matang (ripe ovary, TKG 40 hanya ditemukan $2 \%$ dari seluruh contoh ikan betina sedangkan specimen dalam kondisi mijah (spent) tidak ditemukan. Spesimen ripe ovary ini diduga merupakan telur-telur matang yang akan segera dipijahkan.

\section{Pertama Kali Matang Gonad dan Ukuran Rata-rata Tertangkap}

Dari perhitungan nilai panjang pertama kali matang gonad tiap tahun selama periode 2012-2016 ikan selar bentong betina mencapai matang pertama pada ukuran panjang cagak rata-rata $20.2 \mathrm{~cm}$ Syam et al. (2003) menyebutkan nilai Lm ikan selar bentong betina di perairan Maluku Tengah dan Utara diduga sebesar $22.5 \mathrm{~cm}$. Atmaja et al., (1995) menyebutkan nilai Lm ikan bentong di Laut Jawa sebesar $18.7 \mathrm{~cm}$. Menurut Udupa (1986) perbedaan ukuran pertama kali matang gonad antar jenis maupun di dalam jenis itu sendiri merupakan hal yang bisa terjadi dimana dalam kelas umur yang sama ukuran pertama kali matang dapat mencapai pada panjang yang berbeda. Menurut Nikolskii (1969) apabila ikan-ikan muda yang 
belum matang gonad mengkonsumsi makanan dalam jumlah banyak maka ikan-ikan tersebut akan lebih cepat tumbuh dan mencapai kematangan gonad pada panjang tertentu.

Ukuran pertama kali matang gonad merupakan salah satu variabel dari strategi reproduksi pada ikan, Selain nisbah kelamin, periode dan tipe pemijahan, perkembangan oosit dan fekunditas (Gomiero et al., 2008). Pengamatan ukuran ikan pertama kali matang gonad secara berkala dapat dijadikan indikator adanya tekanan terhadap populasi (Siby et al., 2009). Nilai Lm pada tahun 2012 sebesar 19,3 cmFL kemudian naik menjadi $20,8 \mathrm{cmFL}$ pada tahun 2013. Nilai Lm kemudian cenderung stabil pada tahun 2014-2016 yakni pada ukuran 20,2 cmFL. Beberapa faktor yang diperkirakan menjadi penyebab perbedaan pencapaian matang gonad adalah sifat genetik populasi, perbedaan laju pertumbuhan, dan keadaan kualitas perairan (Paugy, 2002; Laleye et al., 2006), perbedaan wilayah dan tekanan penangkapan (Reynolds et al., 2001, de Graaf et al., 2003). Menurut Lowe-McConnel (1987) dan Moresco \& Bemvenuti (2006), ukuran pertama kali matang gonad pada ikan yang berbeda-beda dan terjadi pada ukuran yang lebih kecil merupakan taktik reproduksi ikan untuk memulihkan keseimbangan populasinya yang disebabkan oleh perubahan kondisi, faktor abiotik, dan tangkap lebih.

Bila dibandingkan antara nilai Lm dan Lc nampak bahwa setiap tahun tren nilai Lc selalu lebih kecil daripada nilai Lm. Nilai Lm rata-rata sebesar 20,2 cmFL sedangkan nlai Lc rata-rata sebesar $18 \mathrm{cmFL}$. Hal ini menunjukkan sebagian besar ikan belum mengalami matang gonad atau memijah. Hal tersebut menunjukkan bahwa hasil tangkapan didominasi oleh ikan-ikan yang belum pernah memijah. Apabila nilai Lc<Lm maka penangkapan ikan selar bentong didominasi ikan muda dan immature (Wujdi et al., 2013). Selanjutnya menurut Najamuddin et al. (2004), secara biologis kalau hal tersebut dibiarkan terus menerus akan berdampak buruk pada berkelanjutan populasi ikan selar bentong. Penangkapan ikan yang didominasi oleh ikan-ikan kecil, maka akan terjadi growth overfishing.

Growth overfishing terjadi apabila hasil tangkapan didominasi oleh ikan-ikan kecil pada ukuran pertumbuhan, sedangkan recruitment overfishing terjadi apabila kegiatan eksploitasi lebih banyak menangkap ikan yang siap memijah (spawning stock) atau ikan dewasa matang gonad (Saputra et al., 2009; Widodo \& Suadi 2006). Menurut Allen et al. (2012) recruitment overfishing adalah bentuk penangkapan ikan yang lebih buruk dan terjadi ketika proses pemijahan berlangsung dan biasanya lebih menggangu keberadaan stok ikan dibandingkan growth overfishing.

\section{Musim Pemijahan}

Peningkatan gonadosomatic index (GSI) mulai terjadi pada akhir musim barat (bulan Maret sampai dengan April), mencapai maksimum sekitar musim timur), yang dilanjutkan dengan penurunan nilai gonado somatic index. GSI kembali mengalami peningkatan pada musim peralihan 2 dan mencapai puncaknya pada awal musim barat kemudian nilai GSI kembali menurun. Bila dilihat dari fluktuasi nilai GSI terlihat bahwa selar bentong di perairan Natuna diduga mengalami dua kali musim pemijahan yakni awal musim barat (Desember) dan pertengahan musim timur (Juni-Juli). Atmaja et al., (1995) mengatakan bahwa musim pemijahan ikan selar bentong di Laut jawa berlangsung pada musim barat sedangkan Zamroni \& Suwarso (2011) menyebutkan bahwa musim pemijahan ikan bentong terjadi pada musim timur. Sedangkan Iwai et al., (1996) menyebutkan bahwa ikan selar bentong di perairan Hawaii memijah dua sampai tiga kali per tahun. Syam et al., (2003) menyebutkan bahwa di perairan Maluku tengah ikan bentong memijah dari bulan Nopember hingga April dan di perairan Maluku Utara pada bulan Nopember dan Desember. Demikian pula Faizah et al., (2011) mengatakan bahwa ikan selar bentong di peraoran Kwandang Gorontallo memijah pada bulan Nopember hingga Januari. Artinya hampir di semua perairan, ikan selar bentong memijah pada musim timur dan barat terutama pada bulan Nopember hingga Januari. Fadzly et al. (2017) mengatakan bahwa di perairan Maldives nilai GSI terendah terjadi pada bulan Januari.

Effendie (2002) mengatakan bahwa musim pemijahan pada ikan berhubungan dengan penyesuaian terhadap keadaan yang menguntungkan terutama yang berhubungan dengan persediaan makanan bagi anakanaknya apabila anak ikan tadi mulai makan makanan yang diambil dari luar setelah persediaan kuning telur habis. Menurut Krismono (2010), kadar klorofil-a dapat digunakan sebagai biomonitoring kualitas dan kesuburan perairan (produktivitas perairan). Castro \& Huber (2007) menyatakan, semua fitoplankton memiliki klorofil terutama sekali klorofil-a. Klorofil berfungsi sebagai katalisator dan penyerap energi cahaya matahari (Strickland, 1960 dalam Riyono, 2007). Makanan utama ikan selar bentong berupa plankton berukuran besar (Roux \& Conand, 2000). Saat muda ikan selar bentong biasa memakan beberapa jenis crustacean (euphausiids. decapods) sedangkan ikan dewasa memangsa larva dan juvenile ikan. Menurut Laevastu \& Hela (1970), pengaruh suhu terhadap ikan adalah dalam proses metabolisme, seperti pertumbuhan dan pengambilan makanan, aktivitas tubuh, seperti kecepatan renang, serta dalam rangsangan syaraf. Pengaruh suhu air pada tingkah laku ikan paling jelas terlihat selama pemijahan. Menurut Nababan \& Simamora (2012), Pada musim barat (Nop-Feb) dan musim peralihan (Apr) tahun ElNino Southern Oscillation (ENSO), 
konsentrasi klorofil-a dan nilai Suhu Permukaan Laut (SPL) di Perairan Natuna secara umum lebih tinggi dibandingkan pada tahun non-ENSO. Secara umum, konsentrasi klorofila di Perairan Natuna berkisar antara 0.11-4.92 mg/m dengan rata-rata $0.56 \mathrm{mg} / \mathrm{m} 3$ pada musim barat dan 0.09 $2.93 \mathrm{mg} / \mathrm{m} 3$ dengan rata-rata $0.66 \mathrm{mg} / \mathrm{m} 3$ pada musim timur.

\section{KESIMPULAN}

Nisbah kelamin ikan selar bentong (Selar crumenophthalmus) jantan dan betina adalah 1:1.05. Sebagian besar $(51 \%)$ ikan dalam stadium pematangan (ripening, TKG 3). Musim memijah ikan selar bentong diduga berlangsung dua kali yakni pada awal musim timur (Juni-Juli) dan awal musim barat (Desember-Januari). Ukuran rata-rata tertangkap $\left(\mathrm{L}_{50 \%}\right)$ sebesar $18 \mathrm{cmFL}$ lebih kecil dari nilai pertama kali matang gonad (Lm) yakni 20,2 cm FL. Nilai Lc yang lebih kecil daripada nilai Lm mengindikasikan terjadinya growth overfishing.

\section{PERSANTUNAN}

Tulisan ini merupakan hasil dari kegiatan riset "Penelitian Karakteristik Biologi Perikanan, Habitat Sumberdaya Dan Potensi Produksi Sumberdaya Ikan di WPP 711 (Laut Cina Selatan dan Selat Karimata)" di Balai Riset Perikanan Laut Tahun 2012, 2013, 2014, 2015 dan 2016.

\section{DAFTAR PUSTAKA}

Allen, M. S., Ahrens, R. N. M., Hansen, M. J., \& Arlinghaus, R. (2012). Dynamic angling efort influences the value of minimum-length limits to prevent recruitment overfishing. Fisheries Management and Ecology Journal. Doi: 10.1111/j.1365-2400.2012.00871. x.

Anonim. (2014). Statistik perikanan tangkap Indonesia. Jakarta. Direktorat Jendral Perikanan Tangkap. Kementerian Kelautan dan Perikanan.

Atmaja, S. B., Sadhotomo, B., \& Suwarso. (1995). Reproduction of main small pelagic species in Java Sea. Workshops Biology, Dynamic, and Exploitation of Small Pelagic in Java Sea. Jakarta.

Ball, D. V., \& Rao, K. V. (1984). Marine Fisheries (p.470). New Delhi: Tata Mcgraw-Hill Publishing Company, Limited.

Budiarti, T. W. (2015). Efisiensi teknis penangkapan pukat cincin di pelabuhan perikanan Nusantara Pemangkat Kabupaten Sambas Provinsi Kalimantan Barat. Thesis. Sekolah Pascasarjana Institut Pertanian Bogor.

Castro, P., \& Huber, M. E. (2007). Marine Biology. Sixth ed. McGraw-Hill Companies. Inc. New York. de Graaf, M., Machiels M., Wudneth, T., \& Sibbing FA. (2003). Length at maturity and gillnet selectivity of Lake Tana's Barbus species (Ethiopia): Implication for management and conservation. Aquatic Ecosystem Health \& Management, 6(3), 325-336.

Effendi, M. I. (1979). Metoda Biologi Perikanan. Bogor. Yayasan Dewi Sri.

Effendi, M. I. (2002). Biologi Perikanan (p.163). Yogyakarta: Yayasan Pustaka Nusatama.

Fadzly, N., Adeeb, S., \& Sah, A. S. R. M. (2017). Some biological aspects of bigeye scad, Selar crumenophthalmus from Bangaa Faru, Maldives. Tropical Life Sciences Research, 28(2), 127-141.

Faizah, R., Sadiya, R., \& Hariati, T. (2014). Parameter populasi dan biologi reproduksi ikan bentong (Selar crumenophthalmus) di perairan Kwandang, Gorontalo Utara. BAWAL, 6(2). 111-117. DOI:http://dx.doi.org/ 10.15578/bawal.6.2.2014.111-117

Genisa, A. S. (1999). Pengenalan jenis-jenis ikan laut ekonomi penting di Indonesia. Jurnal Oseana, (24)1, 17-38.

Gomiero, L. M., Garuana, L., \& Braga, F. M. S. (2008). Reproduction of Oligosarcus hepsetus (Cuvier, 1819) (Characiformes) in the Serra do Mar State Park, São Paulo, Brazil. Brazil. Journal of Biology, 68(1), 187-192.

Hariati, T., Chodriyah, U., \& Taufik, M. (2009). Perikanan pukat cincin di Pemangkat, Kalimantan Barat. J.Lit.Perikan.Ind,, (15)1, 79-91. DOI:http://dx.doi.org/ 10.15578/jppi.15.1.2009.79-91

Hela, I., \& Laevastu, T. (1970). Fisheries Oceanography and Ecology. London: Fishing NewsBook Ltd.

Holden, M. J., \& Raitt, D. F. S. (1974). Manual of Fisheries Sciences Part 2. Methods of Resource Investigation and Their Application (p.214). Rome. Rev. 1. FAO Fish. Tech pap. (115).

Iwai, T. Y., Tamaru, C. S., Yasukochi, L., Alexander, S., Yoshimura, R., \& Mitsuyashu, M. (1996). Natural spawning captive bigeye scad selar crumenophthalmus in Hawaii. Journal of The World Aquaculture Society, 27(3), 332-339.

Kimura, S. (2011). Fishes of terengganu east coast of Malay Peninsula, Malaysia. National Museum of Nature and Science, Universiti Malaysia Terengganu and Kagoshima University Museum. 
Krismono. 2010. Hubungan antara kualitas air dengan klorofil-a dan pengaruhnya terhadap populasi ikan di perairan Danau Limboto. Jurnal Limnotek, 17(2), 171180.

Laleye, P., Chikou, A., Gnohossou, P., Vandewalle, P., Philippart, J. C., \& Teugels, G. (2006). Studies on the biology of two species of Catfish Synodontis schall and Synodontis nigrita (Ostariophysi: Mochokidae) from the Ouèmè River, Bènim. Belgium Journal of Zoology, 136(2), 193-201.

Laevastu, T., \& Hela, I. (1970). Fisheries oceanography. Fishering News, London.

Lowe-Mc Connel, R. H. (1987). Ecological studies in tropical fish communities. London Cambridge University Press.

Moresco, A., \& Bemvenuti, de A. (2006). Biologia reprodutiva do peixe-rei Odontesthes argentinensis (Valenciennes) (Atherinopsidae) da região marinha costeira do sul doBrasil (Reproductive biology of silverside Odontesthes argentinensis (Valenciennes) (Atherinopsidae) of coastal Sea region of the South of Brazil). Revista Brasileira. dezoology, 23(4), 1168-1174.

Nababan, B., \& Simamora, K. (2012). Variabilitas konsentrasi klorofil-a dan suhu permukaan laut di perairan Natuna. Jurnal Ilmu Tropis dan Teknologi Kelautan, 4(1), 121-134

Najamuddin, Achmar, M., Budimawa, N., \& Indar. (2004). Pendugaan ukuran pertama kali matang gonad ikan layang Deles (Decapterus macrosoma, Bleeker). Jurnal Sains dan Teknologi, 4(1), 1-8.

Nikolsky, G. V. (1963). The ecology of fishies (p. 352). London: Academic Press.

Paugy, D. (2002). Reproductive strategies of fishesin a tropical temporary stream of the upper Senegal Basin, Baoule River in Mali. Aquatic Living Resources, 15, 25-35.

Reynolds, J. D., Jennings, S., \& Dulvy, N. K. (2001). Lifehistory of fishes and populatin responses to exploitation. In: Reynolds J.D. Mace G.M. Redford K.H. Robinson J.G. (Eds.). Conservation of Exploited Species. Cambridge University Press. Cambridge. pp. 147-168.

Riyono. (2007). Beberapa sifat umum dari klorofil fitoplankton. Jurnal Oseana. 32(1).
Roux, O., \& Conand, F. (2000). Feeding habits of the bigeye scad, Selar crumenophthalmus (Carangidae), in La Réunion Island Waters (south-western indian ocean). Cybium, 24(2), 173-179.

Saputra, S. W., Soedarsono, P., \& Sulistyawati, G. A. (2009). Beberapa aspek biologi ikan kuniran (Upeneus spp) di perairan Demak. Jurnal Saintek Perikanan, 5(1), 1-6.

Siby, L. S., Rahardjo, M. F., \& Sjafei, D. S. (2009). Biologi reproduksi ikan pelangi merah (Glossolepis incisus weber, 1907) di Danau Sentani. Jurnal Iktiologi Indonesia, 9(1), 49-61.

Steel, R. G. D., \& Torrie, J. H. (1980). Principles and Procedure of Statistic: a Biological Approach (p.512). New York (US): Mic Grow Hill Book Company, Inc.

Suwarso, Zamroni, A., \& Wudianto. (2008). Biologi reproduksi dan dugaan musim pemijahan ikan pelagis kecil di Laut Cina Selatan. J.Lit.Perikan.Ind, 14(4), 379391. DOI:http://dx.doi.org/10.15578/jppi.14.4.2008.379391.

Suwarso \& Sadhotomo, B. (1995). Perkembangan kematangan gonad ikan bentong, Selar crumenophthalmus (CARANGIDAE) di Laut Jawa. Jurnal Penelitian Perikanan Laut. 1(2), 77-88

Syam, A. R., Andamari, R., \& Zubaidi, T. (2003). Aspek biologi ikan kawalinya (Selar crumenopthalmus) di Perairan Sekitar Maluku Tengah dan Maluku Utara. Jurnal Penelitian Perikanan Indonesia Edisi Sumber Daya dan Penangkapan. (9)3, 63-72

Udupa, K. S. (1986). Statistical method of estimating the size at first maturity in fishes. ICLARM, Metro Manila, Fishbyte, 4(2), 8-10.

Widodo, Y., \& Suadi. (2006). Pengelolaan Ssumberdaya perikanan laut. Yogyakarta. Gadjah Mada University Press.

Wujdi, A., Suwarso., \& Wudianto. (2013). Biologi reproduksi dan musim pemijahan ikan lemuru (Sardinella lemuru, Bleeker 1853) di perairan Selat Bali. BAWAL, 5(1), 49-57. DOI:http://dx.doi.org/10.15578/ bawal.5.1.2013.49-57

Zamroni, A. \& Suwarso. (2011). Studi tentang biologi reproduksi beberapa spesies ikan pelagis kecil di perairan laut Banda. BAWAL. (3)5, 337-344. DOI:http:/ /dx.doi.org/10.15578/bawal.3.5.2011.337-344. 
Lampiran 1. Ukuran rata-rata tertangkap L25\%, L50\% dan L75\% ikan bentong di Laut Cina Selatan tahun 2012-2017 Appendix 1. The average size of caught L25\%, L50\% and L75\% of bentong fish in the South China Sea in 2012-2017
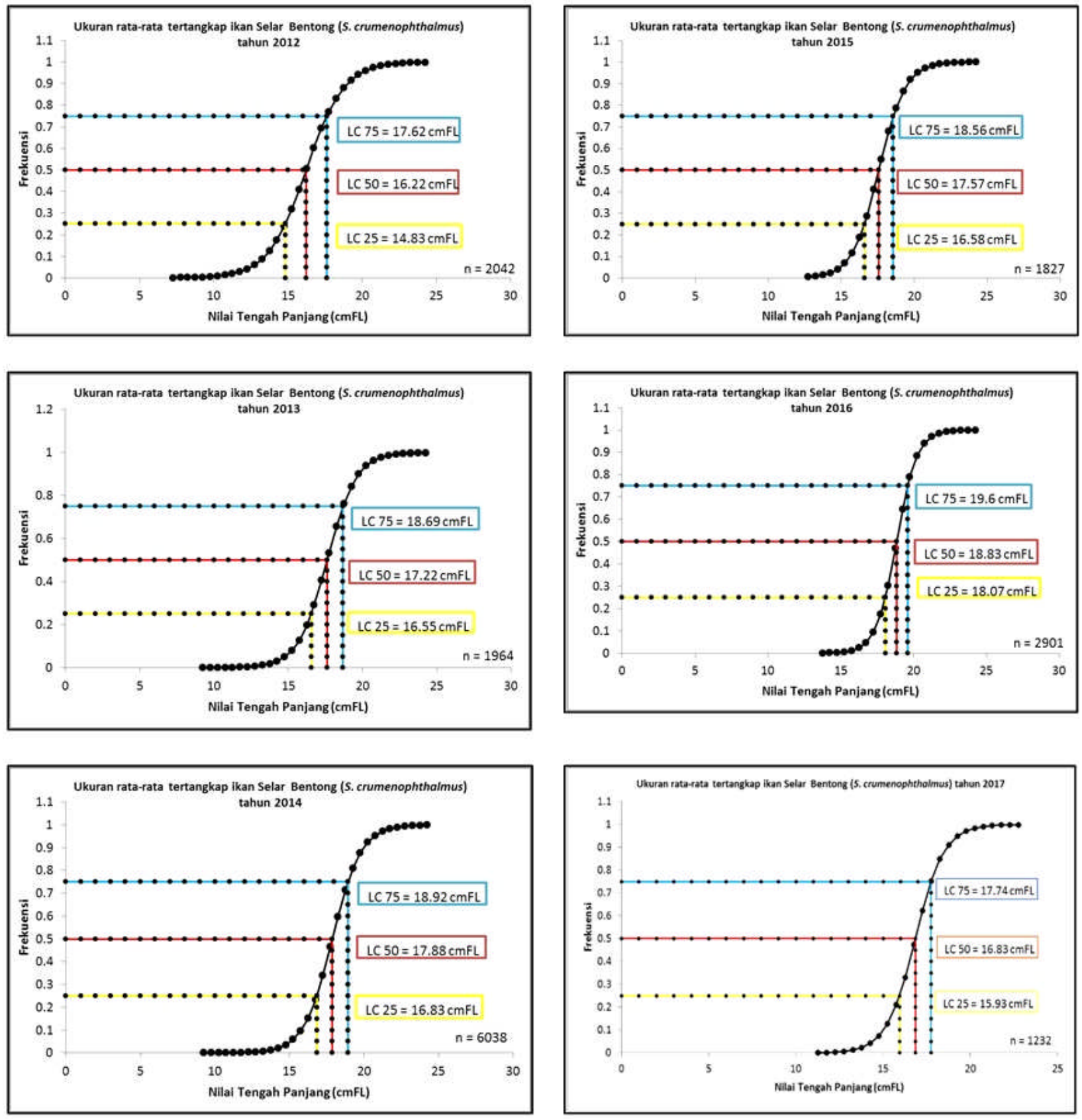